Laksono, R.A. • W.S. Nurcahyo • M. Syafi'i

\title{
Respon pertumbuhan dan hasil beberapa varietas jagung manis (Zea mays Saccharata sturt. L) akibat takaran bokashi pada sistem Pengelolaan Tanaman Terpadu (PTT) di kabupaten Karawang
}

\section{Growth and result response of some sweet maize varieties (Zea mays saccharata sturt. L) due to bokashi dosage on integrated Crop Management System (CMS) in Karawang district}

Diterima : 13 Februari 2018/Disetujui : 13 Maret 2018 / Dipublikasikan : 31 Maret 2018

CDepartment of Crop Science, Padjadjaran University

\begin{abstract}
Sweet corn production in Indonesia can be increased by intensification program, such as the use of superior cultivars, the use of balanced fertilizer, and the use of organic fertilizer. Objective of the research was to study Integrated Crop Management System, that related to use of fermented organic fertilizer (bokashi) which suitable to sweet corn crop, especially in lowland area of Karawang district. The method of research was experiment. The experimental design was Randomized Block Design, that consisted of 16 treatments and 3 replications. The treatments were 4 bokashi dosage $\left(0,5,10\right.$ and 15 ton ha- $\left.{ }^{-1}\right)$ combined with 4 varieties of F1 sweet corn (Bonanza, Talenta, Secada and Sweet Boy). The data were analyzed using analysis of variance and Duncan multiplerange test at $5 \%$. The results show that bokashi dosage had given difference on plant height, number of leaves per plant, diameter of the stem, weight of ears, number of grain rows, and yield. Dosages of 10 tons ha- ${ }^{-1}$ bokashi gave the best growth and sweet corn yield of Sweet Boy F1 varieties on Integrated Crop Management System.
\end{abstract}

Keywords: Sweet Corn, Bokashi, CMS.

Sari. Produksi jagung manis di Indonesia dapat ditingkatkan dengan program intensifikasi, diantaranya dengan penggunaan kultivar unggul, pupuk berimbang, dan pupuk organik. Tujuan penelitian ini adalah untuk mempelajari

\begin{tabular}{l}
\hline Dikomunikasikan oleh Ruminta \\
\hline Laksono, R.A. $\cdot$ W.S. Nurcahyo $\cdot$ M. Syafi'i \\
Staff Pengajar Fakultas Pertanian Universitas \\
Singaperbangsa Karawang Jawa Barat \\
Korespondensi: rommy.laksono@staff.unsika.ac.id
\end{tabular}

sistem pengelolaan tanaman terpadu, yang berhubungan dengan penggunaan pupuk organik bokashi yang cocok pada tanaman jagung manis, khususnya di dataran rendah Karawang. Metode penelitian ini menggunakan percobaan. Rancangan percobaan yang digunakan adalah Rancangan Acak Kelompok, terdiri dari 16 perlakuan dan 3 ulangan. Perlakuan terdiri dari 4 dosis bokashi $\left(0,5,10\right.$ dan 15 ton ha- $\left.{ }^{-1}\right)$ yang dikombinasikan dengan 4 varietas jagung manis F1(Bonanza, Talenta, Secada dan Sweet Boy). Data dianalisis menggunakan analisis varians dan uji jarak berganda Duncan pada taraf 5\%. Hasil menunjukkan perlakuan dosis bokashi memberikan perbedaan pada tinggi tanaman, jumlah daun, diameter batang, berat tongkol, jumlah baris biji, dan hasil. Dosis bokashi 10 ton ha ${ }^{-1}$ memberikan pertumbuhan dan hasil terbaik jagung manis varietas Sweet Boy pada sistem Pengelolaan Tanaman Terpadu.

Kata kunci: Jagung Manis, Bokashi, Pengelolaan Tanaman Terpadu

\section{Pendahuluan}

Indonesia adalah Negara yang beriklim tropis mempunyai prospek yang cukup baik untuk pengembangan jagung. Kebutuhan jagung manis di Indonesia terus meningkat, baik untuk bahan pangan maupun bahan baku industri, namun sampai saat ini belum terpenuhi. Upaya yang dilakukan pemerintah adalah dengan cara impor.

Berdasarkan data, capaian produksi jagung manis untuk tahun 2015 adalah sebesar 19,83 juta ton atau $97 \%$ dari yang ditargetkan. Tahun 
2016, produksi jagung mencapai 23.16 juta ton, atau $96.5 \%$ dari target yang ditetapkan. (BPS, 2017). Hartono (2009), menyatakan bahwa peluang peningkatan produksi jagung manis di Indonesia masih terbuka lebar, yaitu melalui program intensifikasi yang mengacu pada penggunaan "varietas unggul berlabel, penggunaan pupuk berimbang serta penggunaan pupuk organik".

Varietas unggul berlabel, dimaksudkan adalah penggunaan jagung yang unggul dalam hasil, adaptif lingkungan dan tahan terhadap serangan hama dan penyakit. Beberapa varietas jagung manis unggul dapat diperoleh dari jagung hibrida yang dapat ditanam pada daerah dataran rendah diantaranya Bonanza F1, Talenta F1, Secada F1, dan Sweet Boy F1 dengan potensi hasil 18- 25 ton ha ${ }^{-1}$, dengan umur panen antara 65 - 75 Hari Setelah Tanam (HST), tahan terhadap penyakit, serta ukuran yang besar menjadikannya lebih disukai petani dan mudah diterima pasar. Pemanfatana Varietas unggul jagung manis ini ternyata di daerah Karawang belum lazim ditanam, kecuali Bonanza F1, oleh kareannya pemanfaatan varietas unggul ini perlu dicobakan.

Penggunaan pupuk berimbang serta penggunaan pupuk organik, dimaksudkan adalah pengaplikasisn pupuk sesuai kondisi tanah dan kebutuhan tanaman.Kabupaten Karawang merupakan salah satu wilayah yang potensial untuk pengembangan tanaman jagung manis dataran rendah. Daerah dataran rendah ini dibedakan menjadi dua yakni lahan kering (tegalan, kebun, ladang, padang rumput), dan lahan sawah (sawah teknis, setengah teknis, dan tadah hujan. Kondisi lahan pada umumnya memiliki nilai C-Organik 1-2\% (kategori rendah), sehingga hal ini menjadi kendala dalam budidaya jagung manis. Salah satu upaya yang dapat dilakukan adalah dengan Pemberian pupuk organik Menurut Munawar (2005), berguna untuk meningkatkan pengikat air, hara di dalam tanah, aktivitas mikroorganisme, kadar humus, memperbaiki struktur tanah. dan efisien dalam pemakaian pupuk anorganik.

Salah satunya bahan organik yang dapat diaplikasikan adalah dengan memberikan bahan organik yang terfermentasi (bokashi). Bokashi adalah hasil fermentasi bahan organik (jerami, sampah organik, sekam, daun-daunan dan pupuk kandang) dengan bantuan Effektive Mikroorganisme-4 (EM-4). Menurut Marsono dan
Linga (2003) Bokashi dapat menyuburkan tanah melalui pengaruhnya terhadap sifat fisika, kimia dan biologi tanah. Secara fisik bokashi dapat menggemburkan tanah sehingga ruang gerak akar akan bertambah luas, secara kimia bokashi dapat menaikkan $\mathrm{pH}$ tanah, sehingga ketersediaan unsur hara menjadi semakin mudah bagi perakaran tanaman. Secara biologis bokashi dapat meningkatkan populasi mikroorganisme fermentasi dan sintetik. Bokashi juga berfungsi sebagai alat pengendali biologis dalam menekan penyakit tanaman, yaitu dengan cara menghambat pertumbuhan penyakit melalui proses alami dengan meningkatkan antibiotik di dalam inokulon.

Pengaplikasian kedua peluang di atas dalam upaya peningkatan hasil jagung manis, tentunya diperlunya suatu inovasi budidaya yang efektif dan adaptif sesuai kondisi setempat. Caranya adalah dengan teknik Pengelolaan Tanaman Terpadu (PTT) yang inovatif dan dinamis melalui perakitan komponen teknologi secara partisipatif bersama petani. Tata kelola cara ini mempunyai prinsip yaitu: 1) Partisipatif; 2) Petani berperan aktif memilih dan menguji teknologi yang sesuai dengan kondisi setempat, dan meningkatkan kemampuan melalui proses pembelajaran di Laboratorium Lapang (LL); 3) Spesifik lokasi; 4) Kesesuaian teknologi dengan lingkungan fisik, sosial budaya dan ekonomi petani setempat; 5) Terpadu; 6) Sumber daya tanaman, tanah dan air dikelola dengan baik secara terpadu; 7) Sinergis atau Serasi; 8) Pemanfaatan teknologi terbaik, memperhatikan keterkaitan antar komponen teknologi yang saling mendukung; 9) Dinamis; 10) Penerapan teknologi selalu disesuaikan dengan perkem-bangan dan kemajuan IPTEK serta kondisi sosial ekonomi setempat. Adapun beberapa komponen teknologi yang harus diperhatikan pada PTT ini antara lain: menggunakan varietas unggul, benih bermutu dan berlabel, populasi tanaman optimal, pemupukan berdasarkan kebutuhan tanaman dan status hara tanah, penyiapan lahan, pembuatan saluran drainase atau saluran irigasi, pemberian bahan organik dan pengen-dalian OPT yang tepat sasaran (Syafruddin, 2011).

Mengingat keterpaduan peluang peningkatan produksi jagung manis di Karawang masih terbuka lebar, maka pada penggunaan "varietas unggul dan penggunaan pupuk organik bokhasi berbasis PTT menjadi perlu dilakukan". 


\section{Bahan dan Metode}

Penelitian ini dilaksanakan di lahan darat Desa Curug Kecamatan Klari Kabupaten Karawang dengan ketinggian tempat sekitar 50 meter di atas permukaan laut, pada bulan Juni sampai dengan bulan September 2017. Penelitian menggunakan rancangan acak kelompok, terdiri atas 16 perlakuan, diulang $3 \mathrm{kali}$, yaitu 4 perlakuan takaran bokashi $(0,5,10$ dan 15 ton ha-1) yang dikombinasikan dengan 4 varietas jagung F1 (Bonanza, Talenta, Secada dan Sweet Boy) Data dianalisi menggunakan analisis ragam dan uji lanjut dengan uji jarak berganda Duncans pada taraf $5 \%$. Jumlah tanaman sampel untuk tiap petak perlakuan sebanyak 5 tanaman per petak percobaan.

\section{Hasil dan Pembahasan}

Pengamatan Penunjang. Hasil analisis tanah sebelum percobaan menunjukan tanah yang digunakan bertekstur liat (liat $47 \%$, debu $39 \%$, dan pasir $14 \%$ ). Tanah yang bertekstur liat dominan biasanya memiliki drainase yang kurang baik, sehingga perlu dilakukan pengolahan tanah untuk memperbaikinya. Hasil analisis sifat kimia menunjukkan tanah yang digunakan mengandung $\mathrm{pH} \mathrm{H}_{2} \mathrm{O}$ sebesar 5,70 (agak masam). Kandungan unsur hara tanah ditunjukkan dengan nitrogen total sebesar 0,40 \% (sedang), fosfor 37,37 mg (10-2 g) (sedang), kalium 20,35 mg (10-2 g) (rendah), C-organik 1,38 \% (rendah), C/N rasio 3,45 (Sangat rendah), dan KTK 10,91 $\mathrm{cmol} \mathrm{kg}^{-1}$ (rendah). Secara umum hasil analisis tanah memperlihatkan bahwa tanah percobaan termasuk jenis tanah yang kurang subur.

Hasil analisis sifat kimia bokashi menunjukkan bokashi yang digunakan mengandung COrganik 25,78 \%, pH 7,5, C/N rasio 20, Kadar Air $21,16 \%$, dan Hara makro ( $\mathrm{N} \mathrm{1,28 \% ,} \mathrm{P}_{2} \mathrm{O}_{5}$ 1,58\%, $\mathrm{K}_{2} \mathrm{O} \quad 1,40 \%$ ). Berdasarkan ketentuan kriteria penilaian sifat kimia pupuk organik berdasarkan Permentan No.70 Tahun 2011 tentang Pupuk Organik, Pupuk Hayati, dan Pembenah Tanah, maka kandungan bokashi yang digunakan dalam percobaan ini memenuhi persyaratan tersebut.

Suhu harian selama percobaan berlangsung berkisar antara $23,15^{\circ} \mathrm{C}-37,33{ }^{\circ} \mathrm{C}$ dengan ratarata suhu $30,62^{\circ} \mathrm{C}$, sedangkan kelembaban relatif udara antara $22 \%$ - $94 \%$ dengan rata-rata kelembaban $78 \%$.
Selama percobaan dilaksanakan tidak ditemukan adanya serangan penyakit. Hama yang menyerang selama percobaan berlangsung adalah tikus (Rattus argentiventer) hama mulai menyerang petak percobaan saat tanaman berumur 35 HST dengan intensitas serangan 1-2 tanaman per petak atau sekitar $10 \%$. Pengendalian dilakukan secara kimiawi menggunakan Rodentisida yang berbahan aktif Brodifakum $0.005 \%$ umpan beracun berbentuk blok/kotak kubus berwarna kebiruan ditabur disekitar lubang-lubang tikus yang ada di lahan percobaan. Untuk mencegah penyakit meng-gunakan Fungisida sistemik yang berbahan aktif Trifloksistrobin 25\% dan Tebukonazol $50 \%$ juga diberikan dengan dosis $0,4 \mathrm{~g} \mathrm{~L}^{-1}$ air, penyemprotan dilakukan pada sore hari menjelang malam pada umur 14 HST, 28 HST, dan 35 HST. Pengamatan Utama

Tinggi Tanaman. Data hasil analisis menunjukkan bahwa takaran bokashi yang berbeda memberikan pengaruh nyata terhadap tinggi tanaman berbagai varietas jagung manis pada sistem Pengelolaan Tanaman Terpadu (PTT) umur 21 HST, 28 HST, 35 HST, dan 42 HST, tetapi berbeda tidak nyata pada umur 14 HST (Tabel 1).

Pada umur 14 HST takaran bokashi pada beberapa varietas jagung manis pada sistem Pengelolaan Tanaman Terpadu (PTT) memberikan pengaruh tidak nyata pada semua perlakuan (Tabel 1). Hal ini diduga akibat pupuk bokashi yang bersifat organik, sehingga memerlukan waktu agar dapat terdekomposisi secara sempurna. Ini mengkibatkan ketersediaan unsur hara di dalam tanah belum optimal sehingga tanaman belum memberikan pertumbuhan dan perkembangan yang optimal pada fase vegetatif. Musnawar (2005), menyatakan pupuk bokashi merupakan pupuk kompos, juga sama seperti pupuk kandang dan pupuk hijau, merupakan pupuk yang bersifat slow release, artinya unsur hara dalam pupuk dilepaskan secara perlahan-lahan dan terus-menerus dalam jangka waktu tertentu, sehingga unsur hara tidak segera tersedia bagi tanaman.

Pemberian takaran bokashi pada beberapa varietas jagung manis pada sistem Pengelolaan Tanaman Terpadu (PTT) mulai memberikan pengaruh nyata pada tinggi tanaman umur 21 HST, 28 HST, 35 HST, dan 42 HST dengan tinggi tanaman tertinggi diperoleh pada perlakuan 10 ton ha-1 Bokashi + Sweet Boy F1 sebesar $140 \mathrm{~cm}$ 
Tabel 1. Pengaruh takaran bokashi terhadap tinggi tanaman beberapa varietas jagung manis pada sistem Pengelolaan Tanaman Terpadu (PTT).

\begin{tabular}{|c|c|c|c|c|c|c|c|}
\hline \multirow{2}{*}{ Perlakuan } & \multirow{2}{*}{$\begin{array}{l}\text { Takaran Bokashi } \\
\text { (ton ha-1) }\end{array}$} & \multirow{2}{*}{ Varietas } & \multicolumn{5}{|c|}{ Rata-Rata Tinggi Tanaman $(\mathrm{cm})$} \\
\hline & & & $14 \mathrm{HST}$ & $21 \mathrm{HST}$ & $28 \mathrm{HST}$ & $35 \mathrm{HST}$ & $42 \mathrm{HST}$ \\
\hline A (Kontrol) & 0 & Bonanza F1 & $25,86 \mathrm{a}$ & $51,86 a b c$ & $65,06 \mathrm{bcd}$ & 94,94 abcd & $118,67 a b$ \\
\hline B (Kontrol) & 0 & Talenta F1 & $25,78 \mathrm{a}$ & $45,33 \mathrm{bc}$ & $60,58 \mathrm{~d}$ & $82,78 \mathrm{~d}$ & $117,44 \mathrm{ab}$ \\
\hline C (Kontrol) & 0 & Secada F1 & 30,49 a & $60,49 \mathrm{ab}$ & $81,01 \mathrm{ab}$ & 97,67 abcd & $124,01 \mathrm{ab}$ \\
\hline D (Kontrol) & 0 & Sweet Boy F1 & $30,48 \mathrm{a}$ & $60,12 \mathrm{ab}$ & $81,81 \mathrm{ab}$ & 99,00 abcd & $118,35 \mathrm{ab}$ \\
\hline $\mathrm{E}$ & 5 & Bonanza F1 & 24,08 a & $42,53 \mathrm{c}$ & $59,89 \mathrm{~d}$ & $85,17 \mathrm{~d}$ & $108,61 \mathrm{~b}$ \\
\hline $\mathrm{F}$ & 5 & Talenta F1 & 31,98 a & $56,08 a b c$ & $69,53 \mathrm{abcd}$ & 93,94 abcd & $109,44 \mathrm{~b}$ \\
\hline $\mathrm{G}$ & 5 & Secada F1 & 27,96 a & $60,27 \mathrm{ab}$ & $79,56 \mathrm{ab}$ & 91,89 abcd & $113,89 \mathrm{~b}$ \\
\hline $\mathrm{H}$ & 5 & Sweet Boy F1 & $32,62 \mathrm{a}$ & $64,15 \mathrm{a}$ & 85,48 a & $111,78 a b c$ & $129,91 \mathrm{ab}$ \\
\hline I & 10 & Bonanza F1 & $27,78 \mathrm{a}$ & $54,32 \mathrm{abc}$ & 74,10 abcd & $112,72 \mathrm{ab}$ & $138,78 \mathrm{a}$ \\
\hline $\mathrm{J}$ & 10 & Talenta F1 & 24,67 a & $42,39 \mathrm{c}$ & $62,39 \mathrm{~cd}$ & $86,17 \mathrm{~d}$ & $112,00 \mathrm{~b}$ \\
\hline $\mathrm{K}$ & 10 & Secada F1 & 29,31 a & $57,36 a b c$ & $78,71 \mathrm{abc}$ & $90,83 \mathrm{bcd}$ & $111,90 \mathrm{~b}$ \\
\hline $\mathrm{L}$ & 10 & Sweet Boy F1 & 33,37 a & $65,78 \mathrm{a}$ & 86,57 a & $113,61 \mathrm{a}$ & $140,00 \mathrm{a}$ \\
\hline M & 15 & Bonanza F1 & $26,85 \mathrm{a}$ & $50,89 a b c$ & $67,86 \mathrm{bcd}$ & $99,33 \mathrm{abcd}$ & $118,61 \mathrm{ab}$ \\
\hline $\mathrm{N}$ & 15 & Talenta F1 & $27,53 \mathrm{a}$ & $53,22 a b c$ & $67,03 \mathrm{bcd}$ & $89,61 \mathrm{~cd}$ & $111,44 \mathrm{~b}$ \\
\hline $\mathrm{O}$ & 15 & Secada F1 & 29,46 a & $55,74 a b c$ & $82,18 \mathrm{ab}$ & $100,33 \mathrm{abcd}$ & $127,31 \mathrm{ab}$ \\
\hline \multirow[t]{2}{*}{$\mathrm{P}$} & 15 & Sweet Boy F1 & $29,36 \mathrm{a}$ & $56,50 \mathrm{abc}$ & $78,19 \mathrm{abc}$ & $98,33 \mathrm{abcd}$ & $121,31 \mathrm{ab}$ \\
\hline & $\mathrm{CV} \%$ & & 13,04 & 15,46 & 11,97 & 11,79 & 9,72 \\
\hline
\end{tabular}

Keterangan : Nilai rata-rata yang ditandai dengan huruf yang sama pada setiap kolom yang sama tidak berbeda nyata pada uji lanjut DMRT 5\%

Tabel 2. Pengaruh pemberian takaran bokashi terhadap jumlah daun per tanaman beberapa varietas jagung manis pada sistem Pengelolaan Tanaman Terpadu (PTT).

\begin{tabular}{|c|c|c|c|c|c|c|c|}
\hline \multirow{2}{*}{ Perlakuan } & \multirow{2}{*}{$\begin{array}{c}\text { Takaran Bokashi } \\
\text { (ton ha-1) }\end{array}$} & \multirow{2}{*}{ Varietas } & \multicolumn{5}{|c|}{ Rata-Rata Jumlah Daun (Helai) } \\
\hline & & & $14 \mathrm{HST}$ & $21 \mathrm{HST}$ & $28 \mathrm{HST}$ & 35 HST & $42 \mathrm{HST}$ \\
\hline A (Kontrol) & 0 & Bonanza F1 & 4,22 cde & $5,50 \mathrm{~b}$ & $6,39 \mathrm{c}$ & 7,67 ef & $9,17 \mathrm{fg}$ \\
\hline B (Kontrol) & 0 & Talenta F1 & 4,22 cde & $5,11 \mathrm{~b}$ & $6,22 \mathrm{c}$ & 8,78 bcde & $10,61 \mathrm{cdef}$ \\
\hline C (Kontrol) & 0 & Secada F1 & $5,17 \mathrm{ab}$ & $7,33 \mathrm{a}$ & $9,00 \mathrm{a}$ & 10,33 a & $12,44 \mathrm{abc}$ \\
\hline D (Kontrol) & 0 & Sweet Boy F1 & $5,06 \mathrm{abc}$ & $7,00 \mathrm{a}$ & 8,94 a & $9,89 \mathrm{ab}$ & 11,89 abcde \\
\hline $\mathrm{E}$ & 5 & Bonanza F1 & $3,67 \mathrm{e}$ & $5,33 \mathrm{~b}$ & $6,72 \mathrm{bc}$ & $7,17 \mathrm{f}$ & $8,61 \mathrm{~g}$ \\
\hline $\mathrm{F}$ & 5 & Talenta F1 & 4,89 abcd & $5,61 \mathrm{~b}$ & $6,50 \mathrm{bc}$ & 8,44 cdef & $10,50 \mathrm{def}$ \\
\hline G & 5 & Secada F1 & 5,05 abc & $7,28 \mathrm{a}$ & $8,83 \mathrm{a}$ & 9,72 abc & $12,22 \mathrm{abcd}$ \\
\hline $\mathrm{H}$ & 5 & Sweet Boy F1 & $5,17 \mathrm{ab}$ & $7,61 \mathrm{a}$ & $9,33 \mathrm{a}$ & $10,28 \mathrm{a}$ & $12,78 \mathrm{ab}$ \\
\hline I & 10 & Bonanza F1 & $4,11 \mathrm{de}$ & $5,72 b$ & $7,33 \mathrm{~b}$ & 9,17 abcd & 10,89 bcdef \\
\hline $\mathrm{J}$ & 10 & Talenta F1 & 4,33 bcde & $5,56 \mathrm{~b}$ & $6,28 \mathrm{c}$ & $7,33 \mathrm{f}$ & $9,17 \mathrm{fg}$ \\
\hline $\mathrm{K}$ & 10 & Secada F1 & $5,05 \mathrm{abc}$ & 7,16 a & 8,89 a & $9,61 \mathrm{abc}$ & 11,61 abcde \\
\hline $\mathrm{L}$ & 10 & Sweet Boy F1 & $5,22 \mathrm{a}$ & $7,67 \mathrm{a}$ & $9,43 \mathrm{a}$ & 10,39 a & $12,84 \mathrm{a}$ \\
\hline M & 15 & Bonanza F1 & $3,83 \mathrm{e}$ & $5,11 \mathrm{~b}$ & $6,06 \mathrm{c}$ & $8,00 \mathrm{def}$ & $9,56 \mathrm{fg}$ \\
\hline $\mathrm{N}$ & 15 & Talenta F1 & $4,17 \mathrm{de}$ & $5,56 \mathrm{~b}$ & $6,39 \mathrm{c}$ & $8,00 \mathrm{def}$ & 10,28 efg \\
\hline $\mathrm{O}$ & 15 & Secada F1 & $5,17 \mathrm{ab}$ & $7,00 \mathrm{a}$ & $9,00 \mathrm{a}$ & $10,11 \mathrm{a}$ & $12,56 \mathrm{ab}$ \\
\hline $\mathrm{P}$ & 15 & Sweet Boy F1 & 4,78 abcd & $6,89 \mathrm{a}$ & $9,00 \mathrm{a}$ & $9,95 \mathrm{ab}$ & $12,22 \mathrm{abcd}$ \\
\hline & $\mathrm{CV} \%$ & & 9,52 & 8,35 & 6,36 & 7,73 & 9,06 \\
\hline
\end{tabular}

Keterangan : Nilai rata-rata yang ditandai dengan huruf yang sama pada setiap kolom yang sama tidak berbeda nyata pada uji lanjut DMRT 5\%

(umur 42 HST) (Tabel 1). Hal ini diduga pemberian bokashi yang optimal mampu memperbaiki sifat fisik, kimia, dan biologi tanah sehingga mampu meningkatkan pori-pori dan aerasi tanah. Tanah dengan kondisi gembur akan memudahkan akar untuk mendapatkan unsur hara yang dibutuhkan tanaman secara optimal sehingga tanaman akan memaksimalkan proses translokasi unsur hara ke daun dan translokasi potosintat ke seluruh bagian tanaman sehingga mampu meningkatkan pertumbuhan tinggi tanaman di fase vegetatif. Nurhayati (2005), menyatakan bahwa pertumbuhan tanaman yang baik dapat tercapai bila faktor yang mempengaruhi pertumbuhan berimbang dan meguntungkan.

Jumlah Daun per Tanaman. Data Hasil analisis ragam menunjukkan bahwa takaran 
bokashi yang berbeda memberikan pengaruh nyata terhadap jumlah daun per tanaman jagung manis pada sistem Pengelolaan Tanaman Terpadu (PTT) umur 14 HST, 21 HST, 28 HST, 35 HST, dan 42 HST (Tabel 2).

Perlakuan Takaran 10 ton ha-1 Bokashi + Sweet Boy F1 secara berturut-turut memberikan jumlah daun tertinggi pada umur 14 HST, 21 HST, 28 HST, 35 HST, dan 42 HST dengan jumlah daun tertinggi sebesar 12,84 helai (umur 42 HST) (Tabel 2). Hal ini diduga pemberian bokashi dengan takaran yang optimal akan mampu menambah ketersedian unsur $\mathrm{N}$ dalam tanah sehingga mampu memaksimalkan jumlah $\mathrm{N}$ di dalam tanah yang diperoleh dari pemberian 10 ton ha-1 Bokashi pada percoban ini sehingga dapat meningkatkan pertumbuhan daun tanaman jagung varietas Sweet Boy F1. Unsur $\mathrm{N}$ memiliki peranan penting dalam meningkatkan zat hijau daun (klorofil) yang berperan dalam aktivitas fotosintesis sehingga akan mengoptimalkan hasil proses potosintesis yaitu potosintat. Hayati (2006) menyatakan bahwa semakin bertambah jumlah atau luas daun semakin meningkatkan kapasitas fotosintesis sehingga fotosintesis akan berjalan efektif pada daun tanaman jagung mani. Ardi (2010) bahwa luas daun dan jumlah daun tanaman merupakan suatu faktor yang menentukan jumlah energi matahari yang dapat diserap oleh daun dan akan menentukan besarnya fotosintat yang dihasilkan.

Diameter Batang. Hasil analisis ragam menunjukkan bahwa takaran bokashi yang berbeda memberikan pengaruh nyata terhadap diameter batang jagung manis pada sistem Pengelolaan Tanaman Terpadu (PTT) umur 14 HST, 21 HST, 28 HST, 35 HST, dan 42 HST(Tabel 3).

Aplikasi 10 ton ha-1 Bokashi + Sweet Boy F1 secara berturut-turut memberikan diameter batang tertinggi pada umur 14 HST, 21 HST, 28 HST, 35 HST, dan 42 HST dengan diameter batang tertinggi sebesar 28,16 mm (42 HST) (Tabel 3). Hal ini diduga proses pembuatan bokashi menggunakan Mikroorganisme efektif (EM) sehingga mampu mengoptimalkan proses dekomposisi dan meningkatkan jumlah mikroorganisme dalam tanah sehingga meningkatkan jumlah pori-pori tanah yang akan mengoptimalkan kesediaan unsur hara esensial seperti unsur $\mathrm{N}$, yang sangat penting peranannya dalam fase vegetatif salah satunya pembesaran batang tanaman. Menurut Sutejo (2002) unsur nitrogen (N) merupakan unsur hara utama bagi pertumbuhan tanaman, yang pada umumnya sangat diperlukan untuk pembentukan bagian-bagian vegetatif tanaman seperti daun, batang dan akar, sehingga mampu memberikan pengaruh terhadap pertambahan tinggi tanaman, diameter batang dan luas daun.

Tabel 3. Pengaruh pemberian takaran bokashi terhadap diameter batang beberapa varietas jagung manis pada sistem Pengelolaan Tanaman Terpadu (PTT).

\begin{tabular}{|c|c|c|c|c|c|c|c|}
\hline \multirow{2}{*}{ Perlakuan } & \multirow{2}{*}{$\begin{array}{l}\text { Takaran Bokashi } \\
\text { (ton ha-1) }\end{array}$} & \multirow{2}{*}{ Varietas } & \multicolumn{5}{|c|}{ Rata-Rata Diameter Batang (mm) } \\
\hline & & & $14 \mathrm{HST}$ & $21 \mathrm{HST}$ & 28 HST & 35 HST & $42 \mathrm{HST}$ \\
\hline A (Kontrol) & 0 & Bonanza F1 & $3,56 \mathrm{de}$ & 9,97 bcd & $12,38 \mathrm{~cd}$ & $15,92 \mathrm{bc}$ & $21,83 \mathrm{~b}$ \\
\hline B (Kontrol) & 0 & Talenta F1 & 3,99 cde & $9,12 \mathrm{~d}$ & $12,48 \mathrm{~cd}$ & $15,38 \mathrm{c}$ & $21,22 \mathrm{~b}$ \\
\hline C (Kontrol) & 0 & Secada F1 & $6,23 \mathrm{ab}$ & 11,36 abcd & $15,44 \mathrm{abcd}$ & $17,07 \mathrm{bc}$ & $21,78 \mathrm{~b}$ \\
\hline D (Kontrol) & 0 & Sweet Boy F1 & $5,30 \mathrm{abcd}$ & $10,72 \mathrm{bcd}$ & $15,08 \mathrm{abcd}$ & $18,78 \mathrm{abc}$ & $21,33 \mathrm{~b}$ \\
\hline E & 5 & Bonanza F1 & $3,33 \mathrm{e}$ & $9,41 \mathrm{~cd}$ & $13,26 \mathrm{bcd}$ & $15,37 \mathrm{c}$ & $21,75 \mathrm{~b}$ \\
\hline $\mathrm{F}$ & 5 & Talenta F1 & 4,93 abcde & $10,12 \mathrm{bcd}$ & $14,08 \mathrm{abcd}$ & $17,51 \mathrm{abc}$ & $23,65 a b$ \\
\hline G & 5 & Secada F1 & $6,16 a b$ & 11,83 abcd & $14,56 \mathrm{abcd}$ & $17,50 \mathrm{abc}$ & $20,07 \mathrm{~b}$ \\
\hline $\mathrm{H}$ & 5 & Sweet Boy F1 & $6,39 \mathrm{a}$ & $12,40 \mathrm{ab}$ & $16,79 \mathrm{a}$ & $20,02 a b$ & $24,70 a b$ \\
\hline I & 10 & Bonanza F1 & 4,71 abcde & $11,93 a b c$ & $16,73 a b$ & $21,58 \mathrm{a}$ & $28,03 \mathrm{a}$ \\
\hline $\mathrm{J}$ & 10 & Talenta F1 & 4,45 bcde & 9,84 bcd & $12,07 \mathrm{~d}$ & $15,12 \mathrm{c}$ & $21,18 \mathrm{~b}$ \\
\hline K & 10 & Secada F1 & $6,08 \mathrm{ab}$ & 11,24 abcd & $15,37 \mathrm{abcd}$ & $17,53 \mathrm{abc}$ & $20,44 \mathrm{~b}$ \\
\hline $\mathrm{L}$ & 10 & Sweet Boy F1 & $6,54 \mathrm{a}$ & $13,73 \mathrm{a}$ & $17,15 \mathrm{a}$ & $21,60 \mathrm{a}$ & $28,16 \mathrm{a}$ \\
\hline M & 15 & Bonanza F1 & 3,75 cde & $10,71 \mathrm{bcd}$ & $14,59 \mathrm{abcd}$ & $17,43 a b c$ & $23,98 a b$ \\
\hline $\mathrm{N}$ & 15 & Talenta F1 & 4,18 cde & $10,05 \mathrm{bcd}$ & 13,79 abcd & $17,41 \mathrm{abc}$ & $23,55 \mathrm{ab}$ \\
\hline $\mathrm{O}$ & 15 & Secada F1 & $6,35 \mathrm{a}$ & 11,73 abcd & $15,96 \mathrm{abc}$ & $19,24 a b c$ & $22,39 \mathrm{~b}$ \\
\hline $\mathrm{P}$ & 15 & Sweet Boy F1 & $5,60 \mathrm{abc}$ & $11,00 \mathrm{bcd}$ & $15,45 \mathrm{abcd}$ & $18,83 \mathrm{abc}$ & $21,56 \mathrm{~b}$ \\
\hline
\end{tabular}

Keterangan : Nilai rata-rata yang ditandai dengan huruf yang sama pada setiap kolom yang sama tidak berbeda nyata pada uji lanjut DMRT 5\% 
Tabel 4. Pengaruh pemberian takaran bokashi terhadap bobot tongkol berkelobot, dan tanpa kelobot), diameter tongkol kelobot, dan tanpa kelobot) beberapa varietas jagung manis pada sistem Pengelolaan Tanaman Terpadu (PTT).

\begin{tabular}{cclcccc}
\hline Perlakuan & $\begin{array}{c}\text { Takaran Bokashi } \\
\text { (ton ha-1) }\end{array}$ & Varietas & $\begin{array}{c}\text { Bobot Tongkol } \\
\text { Berkelobot (kg) }\end{array}$ & $\begin{array}{c}\text { Bobot Tongkol } \\
\text { Tanpa Kelobot (kg) }\end{array}$ & $\begin{array}{c}\text { Diameter Tongkol } \\
\text { Berkelobot (cm) }\end{array}$ & $\begin{array}{c}\text { Diameter Tongkol } \\
\text { Tanpa Kelobot (cm) }\end{array}$ \\
\hline A (Kontrol) & 0 & Bonanza F1 & $1,17 \mathrm{~cd}$ & $0,70 \mathrm{e}$ & $4,79 \mathrm{a}$ & $4,26 \mathrm{a}$ \\
B (Kontrol) & 0 & Talenta F1 & $1,03 \mathrm{~d}$ & $0,73 \mathrm{e}$ & $4,65 \mathrm{a}$ & $4,33 \mathrm{a}$ \\
C (Kontrol) & 0 & Secada F1 & $1,18 \mathrm{~cd}$ & $0,88 \mathrm{de}$ & $4,86 \mathrm{a}$ & $4,58 \mathrm{a}$ \\
D (Kontrol) & 0 & Sweet Boy F1 & $1,02 \mathrm{~d}$ & $0,72 \mathrm{e}$ & $4,46 \mathrm{a}$ & $4,06 \mathrm{a}$ \\
E & 5 & Bonanza F1 & $1,23 \mathrm{~cd}$ & $0,93 \mathrm{de}$ & $4,60 \mathrm{a}$ & $4,16 \mathrm{a}$ \\
F & 5 & Talenta F1 & $1,33 \mathrm{bcd}$ & $1,03 \mathrm{cde}$ & $5,11 \mathrm{a}$ & $4,57 \mathrm{a}$ \\
G & 5 & Secada F1 & $1,36 \mathrm{bcd}$ & $1,02 \mathrm{cde}$ & $4,35 \mathrm{a}$ & $4,13 \mathrm{a}$ \\
H & 5 & Sweet Boy F1 & $1,31 \mathrm{bcd}$ & $1,01 \mathrm{cde}$ & $4,45 \mathrm{a}$ & $4,03 \mathrm{a}$ \\
I & 10 & Bonanza F1 & $1,69 \mathrm{ab}$ & $1,43 \mathrm{ab}$ & $5,23 \mathrm{a}$ & $4,56 \mathrm{a}$ \\
J & 10 & Talenta F1 & $1,53 \mathrm{abc}$ & $1,33 \mathrm{abc}$ & $4,83 \mathrm{a}$ & $4,21 \mathrm{a}$ \\
K & 10 & Secada F1 & $1,53 \mathrm{abc}$ & $1,23 \mathrm{bcd}$ & $4,50 \mathrm{a}$ & $4,15 \mathrm{a}$ \\
L & 10 & Sweet Boy F1 & $1,81 \mathrm{a}$ & $1,58 \mathrm{a}$ & $4,49 \mathrm{a}$ & $4,05 \mathrm{a}$ \\
M & 15 & Bonanza F1 & $1,17 \mathrm{~cd}$ & $0,87 \mathrm{de}$ & $4,85 \mathrm{a}$ & $4,49 \mathrm{a}$ \\
N & 15 & Talenta F1 & $1,28 \mathrm{bcd}$ & $0,98 \mathrm{cde}$ & $4,92 \mathrm{a}$ & $4,45 \mathrm{a}$ \\
O & 15 & Secada F1 & $1,33 \mathrm{bcd}$ & $1,07 \mathrm{cde}$ & $4,98 \mathrm{a}$ & $4,69 \mathrm{a}$ \\
P & 15 & Sweet Boy F1 & $1,10 \mathrm{~cd}$ & $0,87 \mathrm{de}$ & $4,56 \mathrm{a}$ & $4,11 \mathrm{a}$ \\
\hline
\end{tabular}

Keterangan : Nilai rata-rata yang ditandai dengan huruf yang sama pada setiap kolom yang sama tidak berbeda nyata pada uji lanjut DMRT 5\%

Peningkatan ukuran batang juga diduga akibat varietas Sweet Boy F1 memiliki kemampuan menyerap unsur hara, menyesuaiakan kondisi iklim mikro, dan adaptasi yang lebih baik dibanding varietas unggul lainya, sehingga pertumbuhan vegetatifnya optimal. Menurut Sadjad (1993), perbedaan daya tumbuh antar varietas yang berbeda ditentukan oleh faktor genetiknya. Selain itu, potensi gen dari suatu tanaman akan lebih maksimal jika didukung oleh faktor lingkungan.

Bobot Tongkol Berkelobot, dan Tanpa Kelobot, Diameter Tongkol Berkelobot, dan Tanpa Kelobot. Hasil uji analisis ragam menunjukkan bahwa pemberian takaran bokashi yang berbeda memberikan pengaruh nyata terhadap bobot tongkol (dengan berkelobot dan tanpa kelobot), tetapi berbeda tidak nyata pada diameter tongkol (berkelobot dan tanpa kelobot ) jagung manis pada sistem Pengelolaan Tanaman Terpadu (PTT) (Tabel 4).

Dari Tabel 4 tampak bahwa takaran 10 ton ha ${ }^{-1}$ Bokashi + Sweet Boy F1 memberikan hasil bobot tongkol dengan berkelobot tertinggi sebesar $1,81 \mathrm{~kg}$, tetapi tidak berbeda nyata dengan varietas Bonanza F1, Talenta F1 dan Secada F1 pada takaran 10 ton ha-1 Bokashi. Hal ini diduga takaran 10 ton ha-1 Bokashi merupakan takaran yang optimal sehingga mampu menyuplai ketersediaan unsur hara yang dibutuhkan tanaman untuk proses generatifnya. Dwijosaputro (1997) tanaman tumbuh subur apabila unsur yang diperlukan cukup tersedia dan berada dalam dosis yang sesuai untuk diserap tanaman, sehingga mampu memberikan hasil lebih baik bagi tanaman.

Dari sidik ragam dapat dilihat bahwa perlakuan 10 ton ha-1 Bokashi + Sweet Boy F1 memberikan hasil bobot tongkol tanpa kelobot tertinggi sebesar 1,58 $\mathrm{kg}$ (Tabel 4), tetapi berbeda tidak nyata dengan varietas Bonanza F1 dan Talenta F1 pada takaran 10 ton ha-1 Bokashi. Hal ini diduga varietas Sweet boy F1, Bonanza F1 dan Talenta F1 adalah varietas unggul yang memiliki kemampuan merespon unsur hara lebih optimal dibandingkan varietas Secada F1 pada takaran 10 ton ha-1 Bokashi pada kondisi iklim mikro dan kondisi tanah di tempat percobaan yang kurang ideal. Selain itu, varietas Sweet boy F1, Bonanza F1 dan Talenta F1 memiliki kemampuan beradaptasi yang baik terhadap lingkungan sehingga berdampak pada produksi atau hasil tanaman itu sendiri. Sesuai dengan penyataan Doni (2008) apabila pertumbuhan tanaman terhambat, maka kelancaran translokasi unsur hara dan fotosintat kebagian tongkol juga akan terhambat. Akibatnya, berat tongkol tanaman jagung akan ringan sehingga produksinya akan sedikit.

Hasil analisis ragam menunjukan bahwa takaran bokashi yang berbeda pengaruh tidak nyata terhadap diameter tongkol berkelobot dan tanpa kelobot jagung manis pada sistem Pengelolaan Tanaman Terpadu (PTT). Hal ini diduga penggunaan varietas unggul hibrida memiliki karakter komponen hasil yang hampir sama, baik diameter tongkol diameter tongkol 
berkelobot dan tanpa kelobot dengan deskripsi masing-masing varietas yakni sekitar $2-4 \mathrm{~cm}$. Jagung manis hibrida sangat menonjol peranannya, baik dalam peningkatan hasil per satuan luas maupun tingkat adaktifnya pada suatu lingkungan, karena rendahnya hasil bisa disebabkan oleh kurang tanggapnya tanaman terhadap kondisi lingkungan (Made, 2010). Menurut Widiyawati, I. (2016) tidak adanya perbedaan sifat antar varietas yang dipengaruhi oleh faktor genetik dan kondisi lingkungan

Panjang Tongkol Tanpa Kelobot, Jumlah Baris Biji Per Tongkol, Bobot Tongkol Berkelobot Per Petak, Dan Bobot Hijauan. Hasil uji analisis ragam menunjukkan bahwa takaran bokashi yang berbeda memberikan pengaruh nyata terhadap jumlah baris biji per tongkol, Bobot Tongkol Berkelobot Per Petak, dan bobot hijauan tetapi tidak berbeda nyata pada panjang tongkol tanpa kelobot jagung manis pada sistem Pengelolaan Tanaman Terpadu (PTT) (Tabel 5).

Hasil analisis ragam menunjukan bahwa takaran bokashi yang berbeda memberikan pengaruh tidak nyata terhadap panjang tongkol tanpa kelobot. Hal ini diduga faktor fisiologi yang hampir sama dari varietas unggul hibrida, ini dapat dibuktikan dari deskripsi ke empat varietas unggul ini yang memiliki panjang tongkol $17-23 \mathrm{~cm}$. Ini membuktikan bahwa tanaman sangat dipengaruhi faktor genetik selain faktor lingkungan. Gardner, Pearce dan Mitchell (1991) menyatakan faktor internal perangsang pertumbuhan tanaman ada dalam kendali genetik, tetapi unsur-unsur iklim, tanah, dan biologi seperti hama, penyakit dan gulma serta persaingan antar spesies maupun luar spesies juga mempengaruhinya.

Dari hasil pengamatan dan sidik ragam dapat dilihat bahwa perlakuan 10 ton ha- ${ }^{-1}$ Bokashi + Sweet Boy F1 memberikan hasil jumlah baris biji per tongkol tertinggi mencapai 16,30 buah (Tabel 5). Hal ini diduga Pertambahan panjang tongkol jagung manis memungkinkan banyaknya biji yang akan terbentuk pada tongkol jagung manis. Dalam hal ini kebutuhan energi untuk pembentukan biji jagung manis semakin meningkat (Puspadewi, S.dkk, 2006). Syafruddin dkk., (2011), pemberian unsur hara secara akurat harus sesuai dengan kebutuhan tanaman dan status hara dalam tanah untuk mencapai tujuan peningkatan produktivitas, efisiensi dan kelestarian lingkungan. Hara yang tidak diserap oleh tanaman akan terurai di dalam tanah.

Dari hasil pengamatan dan sidik ragam dapat dilihat bahwa perlakuan 10 ton ha-1 Bokashi + Sweet Boy F1 memberikan Bobot Tongkol Berkelobot Per Petak tertinggi mencapai $10,39 \mathrm{~kg}$ dan bobot hijauan tertinggi mencapai $8,92 \mathrm{~kg}$. Hal ini diduga pemberian dosis bokashi yang optimal mampu meningkatkan kandungan unsur hara dalam tanah untuk diserap oleh akar tanaman dan meningkatkan kestabilan kondisi fisika, kimia, dan biologi tanah. Bokashi merupakan pupuk organik yang proses dekomposernya (fermentasi) dipengaruhi oleh mikroba dekomposer.

Tabel 5. Pengaruh pemberian takaran bokashi terhadap panjang tongkol tanpa kelobot, jumlah baris biji per tongkol, Bobot Tongkol Berkelobot Per Petak, dan bobot hijauan per petak beberapa varietas jagung manis pada sistem Pengelolaan Tanaman Terpadu (PTT).

\begin{tabular}{cclcccc}
\hline Perlakuan & $\begin{array}{c}\text { Takaran Bokashi } \\
\text { (ton ha-1) }\end{array}$ & Varietas & $\begin{array}{c}\text { Panjang Tongkol } \\
\text { Tanpa Kelobot (cm) }\end{array}$ & $\begin{array}{c}\text { Jumlah Baris Biji } \\
\text { Per Tongkol (Baris) }\end{array}$ & $\begin{array}{c}\text { Bobot Tongkol } \\
\text { Berkelobot Per Petak }\end{array}$ & Bobot Hijauan Per Petak (kg) \\
\hline A (Kontrol) & 0 & Bonanza F1 & $18,07 \mathrm{a}$ & $14,30 \mathrm{bcd}$ & $7,45 \mathrm{bc}$ & $6,00 \mathrm{f}$ \\
B (Kontrol) & 0 & Talenta F1 & $17,52 \mathrm{a}$ & $12,62 \mathrm{~d}$ & $6,43 \mathrm{c}$ & $6,63 \mathrm{def}$ \\
C (Kontrol) & 0 & Secada F1 & $19,88 \mathrm{a}$ & $14,11 \mathrm{bcd}$ & $7,56 \mathrm{bc}$ & $6,37 \mathrm{ef}$ \\
D (Kontrol) & 0 & Sweet Boy F1 & $18,64 \mathrm{a}$ & $14,11 \mathrm{bcd}$ & $7,29 \mathrm{c}$ & $7,60 \mathrm{abcde}$ \\
E & 5 & Bonanza F1 & $17,08 \mathrm{a}$ & $13,64 \mathrm{~cd}$ & $7,60 \mathrm{bc}$ & $7,50 \mathrm{bcde}$ \\
F & 5 & Talenta F1 & $19,72 \mathrm{a}$ & $14,46 \mathrm{abcd}$ & $7,73 \mathrm{bc}$ & $7,53 \mathrm{bcde}$ \\
G & 5 & Secada F1 & $17,42 \mathrm{a}$ & $15,22 \mathrm{abc}$ & $7,96 \mathrm{bc}$ & $7,27 \mathrm{cde}$ \\
H & 5 & Sweet Boy F1 & $18,33 \mathrm{a}$ & $13,55 \mathrm{~cd}$ & $8,29 \mathrm{abc}$ & $7,73 \mathrm{abcd}$ \\
I & 10 & Bonanza F1 & $19,97 \mathrm{a}$ & $16,05 \mathrm{ab}$ & $7,90 \mathrm{bc}$ & $8,70 \mathrm{ab}$ \\
J & 10 & Talenta F1 & $17,77 \mathrm{a}$ & $13,31 \mathrm{~cd}$ & $8,53 \mathrm{abc}$ & $7,97 \mathrm{abcd}$ \\
K & 10 & Secada F1 & $18,45 \mathrm{a}$ & $15,89 \mathrm{ab}$ & $8,17 \mathrm{abc}$ & $7,67 \mathrm{abcde}$ \\
L & 10 & Sweet Boy F1 & $18,00 \mathrm{a}$ & $16,30 \mathrm{a}$ & $10,39 \mathrm{a}$ & $8,92 \mathrm{a}$ \\
M & 15 & Bonanza F1 & $19,58 \mathrm{a}$ & $14,86 \mathrm{abc}$ & $7,72 \mathrm{bc}$ & $8,37 \mathrm{abc}$ \\
N & 15 & Talenta F1 & $19,26 \mathrm{a}$ & $14,36 \mathrm{abcd}$ & $7,05 \mathrm{c}$ & $7,57 \mathrm{abcde}$ \\
O & 15 & Secada F1 & $20,74 \mathrm{a}$ & $15,78 \mathrm{ab}$ & $9,87 \mathrm{ab}$ & $7,90 \mathrm{abcd}$ \\
P & 15 & Sweet Boy F1 & $18,44 \mathrm{a}$ & $14,89 \mathrm{abc}$ & $9,79 \mathrm{ab}$ & $8,13 \mathrm{abc}$ \\
\hline
\end{tabular}

Keterangan : Nilai rata-rata yang ditandai dengan huruf yang sama pada setiap kolom yang sama tidak berbeda nyata pada uji lanjut DMRT 5\% 
Bokashi mengandung unsur hara makro dan mikro juga mengandung senyawa organik, asam amino, protein, gula, alkohol dan mikroorganisme pengurai sendiri. Secara fisik bokashi dapat menggemburkan tanah sehingga ruang gerak akar akan bertambah luas, secara kimia bokashi dapat menaikkan $\mathrm{pH}$ tanah dan meningkatkan Kapasitas Tukar Kation (KTK) tanah, sehingga penyerapan unsur hara menjadi semakin mudah bagi perakaran tanaman. Secara biologis bokashi dapat meningkatkan populasi mikroorganisme fermentasi dan sintetik. Bokashi juga berfungsi sebagai alat pengendali biologis dalam menekan penyakit tanaman, yaitu dengan cara menghambat pertumbuhan penyakit melalui proses alami dengan meningkatkan antibiotik di dalam inokulean (Cahyani, dkk. 2003)

Hal ini bisa terjadi karena melihat kondisi tanah yang digunakan secara umum memiliki tingkat kesuburan yang rendah, dengan kandungan unsur hara tanah ditunjukkan dengan nitrogen total sebesar 0,40\% (sedang), fosfor 37,37 $\mathrm{mg}\left(10^{-2} \mathrm{~g}\right)$ (sedang), kalium 20,35 $\mathrm{mg}\left(10^{-2} \mathrm{~g}\right)$ (rendah), C-organik 1,38 \% (rendah), C/N rasio 3,45 (Sangat rendah), dan KTK 10,91 $\mathrm{cmol} \mathrm{kg}^{-1}$ (rendah).

Peningkatan komponen pertumbuhan tanaman jagung manis dapat diduga pula terjadi akibat penerapan prinsip Pengelolaan Tanaman Terpadu (PTT) yang optimal, salah satunya penggunaan varietas unggul spesifikasi lokasi dan jumlah populasi yang optimal, karena kerapatan tanaman akan mempengaruhi suplai sinar matahari, suhu, kelembaban dan transfirasi tanaman yang akan mempengaruhi proses pertumbuhan tanaman jagung manis. Selain itu jumlah populasi yang optimal akan membuat tanaman jagung manis memperoleh suplai unsur hara optimal yang berasal dari bokashi. Sesuai dengan pernyataan Syafruddin (2011) Ada beberapa komponen teknologi yang harus diperhatikan pada PTT ini antara lain: varietas unggul, benih bermutu dan berlabel, populasi tanaman optimal, pemupukan berdasarkan kebutuhan tanaman dan status hara tanah, penyiapan lahan, pembuatan saluran drainase atau saluran irigasi, pemberian bahan organik dan pengendalian OPT yang tepat sasaran. Adnan (2006) menyatakan bahwa faktor-faktor yang mempengaruhi hasil pertanian adalah jenis tanaman, varietas, tempat tumbuh, iklim, kesuburan tanah dan kadar air bahan tersebut.

Faktor lingkungan dalam percobaan ini juga diduga memberikan pengaruh terhadap peningkatan komponen pertumbuhn dan hasil. Melihat kondisi suhu yang tinggi berkisar antara 23,15-37,33 ${ }^{\circ} \mathrm{C}$ memungkinkan meningkatnya laju proses fotosintetis, sehingga produksi fotosintat semakin optimal dan berbanding lurus dengan ketersediaan cadangan makanan pada fase generatif. Jedeng (2011), bahwa secara umum tinggi rendah suatu hasil atau produksi tanaman tergantung varietas, cara bercocok tanam, dan kondisi lingkungan tempat tanaman tersebut di tanam.

\section{Kesimpulan}

Pemberian bokashi dengan berbeda takaran memberikan pengaruh nyata pada beberapa varietas jagung manis terhadap pertumbuhan tanaman tinggi tanaman umur 21 HST, 28 HST, 35 HST, jumlah daun per tanaman umur 14 HST, 21 HST, 28 HST, 35 HST, dan 42 HST, dan hasil diameter batang umur 14 HST, 21 HST, 28 HST, 35 HST, dan 42 HST, bobot tongkol berkelobot, dan tanpa kelobot, jumlah baris biji, Bobot Tongkol Berkelobot Per Petak, dan bobot hijauan per petak, pada sistem Pengelolaan Tanaman Terpadu (PTT). Pemberian 10 ton ha ${ }^{-1}$ bokashi memberikan pertumbuhn dan hasil terbaik jagung manis varietas Sweet Boy F1 pada sistem Pengelolaan Tanaman Terpadu (PTT) dengan hasil Bobot Tongkol Berkelobot tertinggi mencapai $10,39 \mathrm{~kg}$ per petak atau 17,32 ton per hektar.

\section{Ucapan Terima Kasih}

Peneliti mengucapkan terimaksih kepada KEMENRISTEKDIKTI, Rektor UNSIKA, Dekan Faperta UNSIKA dan LPPM UNSIKA yang telah memberikan kesempatan dan membiayai penelitian ini melalui skema Penelitian Dosen Pemula (PDP) Tahun 2017, serta Jurnal Kultivar UNPAD yang memberikan kesempatan kepada kami dalam mempublikasikan hasil penelitian ini.

\section{Daftar Pustaka}

Adnan, A.A. 2006. Karakterisasi fisiko kimia dan mekanis kelobot jagung sebagai bahan kemasan. Skripsi Fakultas Teknologi Pertanian Institut Pertanian Bogor, Bogor. (Tidak dipublikasikan). 
Ardi, A. 2010. Pengaruh Takaran Pupuk Kandang Dan Interval Pemberian Pupuk Hayati Terhadap Pertumbuhan Dan Hasil Jagung Manis (Zea mays saccharata). J. Agronobis 2(4): 267-277.

Badan Pusat Statistik. 2016. Data produksi jagung manis Indonesia tahun 2015-2016. BPS. Jakarta

Cahyani, Sri Susanti. 2003. Pengaruh Pemberian Bokashi Terhadap Sifat Fisik dan Mekanik Tanah serta Pertumbuhan Tanaman Pak Choi (Brassica chinensis L), sebuah skripsi. Dalam IPB Repository diunduh 12 Juni 2013.

Dwidjosaputro. 1997. Pengantar Fisiologi Tumbuhan. Gramedia. Jakarta.

Doni. 2008. Pengaruh Dosis dan Waktu Pemberian Pupuk N dan K Terhadap Pertumbuhan dan Produksi Jagung Manis Seleksi Dermaga 2 (SD2). J.II. Pert. Indonesia 2(1): 1-6.

Gardner, Pearce dan Mitchell. 1991. Fisiologi Tumbuhan Budidaya Universitas Indonesia. Alih bahasa : Susilo dan Subiyanto. UI. Press, Jakarta. Hal 167

Hartono, Dwi. 2009. Budidaya Jagung. http://www. starfarmagris.co.cc/2009/04/budidaya-jagung manis-memanfaatkan-peluang_11.html. Di akses tanggal 17 April 2011

Hayati, N. 2006. Pertumbuhan dan Hasil Jagung Manis pada Berbagai Waktu Aplikasi Bokashi Limbah kulit Buah kakao dan Pupuk Anorganik. J. Agroland 13 (3):256 - 259.

Jedeng, I.W. 2011. Pengaruh Jenis Dan Dosis Pupuk Organik Terhadap Pertumbuhan Dan Hasil Ubi Jalar (Ipomoea batatas (L.) Lamb.) Var. Lokal ungu. Tesis. Universitas
Udayana, Denpasar.dalam Widiyawati, I.dkk. Aplikasi pupuk organik terhadap hasil kacang hijau (Vigna radiate L.) di ultisol. Jurnal Kultivasi Vol. 15(3) Desember 2016. Hal 159-163

Made, U. 2010. Respons Berbagai Populasi Tanaman Jagung Manis (Zea mays saccharata Sturt) terhadap Pemberian Pupuk Urea. J. Agroland 17 (2): 138-143.

Marsono dan P, Linga. 2003. Petunjuk Pengunan Pupuk. Penebar Swadaya. Jakarta, hal.45.

Munawar. 2005. Kesuburan Tanamandan Nutrisi Tanaman. IPB Press, Bogor. Hal, 235.

Nurhayati 2005. Pemanfaatan Lahan Pertanian Untuk Tanaman Pangan. Penebar Swadaya. Jakarta. hal. 56.

Puspadewi, S.dkk. Pengaruh konsentrasi pupuk organik cair (POC) dan dosis pupuk N, P, $\mathrm{K}$ terhadap pertumbuhan dan hasil tanaman jagung manis (Zea mays L. var Rugosa Bonaf) kultivar Talenta. Jurnal Kultivasi Vol. 15(3) Desember 2016. Hal. 208-216.

Sadjad, S. 1993. Dari Benih Kepada Benih. Grasindo, Jakarta. Halaman 38.

Sutejo, M. 2002. Pupuk dan Cara Pemupukan. Rineka Cipta, Jakarta. Halaman, 35.

Syafruddin.2011.Modifikasi Sistem Pertanaman Jagung dan Pengolahan brangkasan untuk Meningkatkan Pendapatan Petani di lahan Kering. Majalah Litbang Pertanian. 30(1):1622.

Widiyawati, I. dkk. Aplikasi pupuk organik terhadap hasil kacang hijau (Vigna radiate L.) di ultisol. Jurnal Kultivasi Vol. 15(3) Desember 2016. Hal 159-163 